\title{
CEGAH PENULARAN COVID-19 DENGAN MENJAGA KEBERSIHAN TANGAN PADA PANTI DI WILAYAH BANDA ACEH
}

\author{
Laras Cyntia Kasih ${ }^{1}$, Rachmah $^{2}$, Rahmawati ${ }^{3}$, Jufrizal $^{4}$, Mayanti Mahdarsari ${ }^{5}$ \\ 1,2,3,4,5 Fakultas Keperawatan Universitas Syiah Kuala \\ larascynthiakasih@unsyiah.ac.id'
}

Submited : 4 Agustus 2020

Acepted : 12 Agustus 2020

Published : Desember 2020

\begin{abstract}
Abstrak
Pengabdian kepada masyarakat ini merupakan salah satu kegiatan pengabdian dosen keperawatan untuk merespon terhadap munculnya pandemic global Coronavirus Disease-19 (COVID-19) di Indonesia. COVID-19 telah menyebabkan begitu banyak angka kesakitan dan kematian di Indonesia. Virus ini begitu cepat menyebar dan menginfeksi seluruh tingkatan umur. Permasalahan yang terjadi pada masyarakat adalah kurangnya pengetahuan dalam mencegah corona virus masuk, seperti masih kurangnya menjaga kebersihan tangan baik sebelum maupun setelah beraktifitas. Pelaksanaan Pengabdian kepada masyarakat dimulai dengan membuat video yang berisi pendidikan kesehatan tentang menjaga kebersihan tangan sehingga tidak dilakukan pengumpulan massa. Tujuan dari pengabdian kepada masyarakat ini adalah meningkatakan pemahaman masyarakat khususnya penghuni panti tentang kebersihan tangan untuk mencegah penularan COVID-19. Hasil dari pengabdian kepada masyarakat ini didapatkan peningkatan pemahaman penghuni panti setelah pemberian pendidikan kesehatan dalam menjaga kebersihan tangan, hal ini ditunjukan dengan kemampuan para penghuni panti melakukan kembali proses mencuci tangan yang benar menurut standar WHO dan penggunaan handsanitizer yang tepat. Maka, dengan adanya pendidikan kesehatan mampu meningkatkan pemahaman masyarakat terhadap kebersihan tangan dan diharapkan dapat menjadi salah satu cara mencegah penularan COVID-19.
\end{abstract}

Kata Kunci : Covid-19, Kebersihan tangan, Panti, Pencegahan, Penularan 


\section{PENDAHULUAN}

Coronavirus (CoV) adalah keluarga besar virus yang menyebabkan penyakit mulai dari gejala ringan sampai berat. Ada setidaknya dua jenis coronavirus yang diketahui menyebabkan penyakit yang dapat menimbulkan gejala berat seperti Middle East Respiratory Syndrome (MERS) dan Severe Acute Respiratory Syndrome (SARS). Coronavirus Disease -19 (COVID-19) adalah virus jenis baru yang belum pernah diidentifikasi sebelumnya pada manusia. Virus corona adalah zoonosis (ditularkan antara hewan dan manusia), (Direktorat Jendral P2P, 2020).

Virus corona umum terutama menginfeksi orang dewasa atau anak-anak yang usianya lebih tua, menyebabkan flu biasa. Beberapa turunannya dapat menyebabkan diare pada orang dewasa. Virus-virus ini sebagian besar ditularkan melalui percikan (droplet), dan juga dapat menyebar melalui rute penularan kotoran dan mulut (fecal-oral). Insiden infeksi virus corona lazim terjadi di musim dingin dan musim semi. Masa inkubasi untuk virus corona biasanya 3 sampai 7 hari.

Orang yang terinfeksi dapat menyebarkan virus ini ke orang yang sehat. Melalui mata, hidung, dan mulut, lewat tetesan cairan saat batuk atau bersin. Kontak/bersentuhan dekat dengan orang yang terinfeksi. Bersentuhan dengan permukaan, benda, atau barang pribadi yang terkontaminasi, (halodoc, 2020). Maka dari itu salah satu cara mengendalikan sumber infeksi ketika batuk atau bersin, orang dengan penyakit pernapasan akut harus menutup hidung dan mulut mereka dengan lengan atau bahan lain (saputangan, handuk kertas, atau masker) untuk mengurangi penularan percikan. Setelah terpapar sekret pernapasan, segera bersihkan tangan, dan sering-seringlah mencuci tangan dalam kehidupan sehari-hari.

Permasalahan yang terjadi pada masyarakat adalah kurangnya pengetahuan dalam mencegah corona virus masuk, seperti masih kurangnya menjaga kebersihan tangan baik sebelum maupun setelah beraktivitas. Pengabdian mandiri tematik ini merupakan salah satu kegiatan pengabdian dosen keperawatan untuk merespon terhadap munculnya pandemic global Coronavirus Disease-19 di Indonesia yang telah menjadi perhatian dunia. COVID-19 telah menyebabkan setidaknya 535 kematian di Indonesia, serta 6 orang terkonfirmasi positif di Aceh per-tanggal 18 April 2020. Penyebaran virus dan penambahan korban yang begitu cepat telah menjadi fokus seluruh lapisan masyarakat begitu pula para Sivitas akademika.

\section{TINJAUAN PUSTAKA}

Virus Corona adalah virus RNA untai positif yang beruntai tunggal yang tidak tersegmentasi. Virus-virus corona termasuk dalam ordo Nidovirales, keluarga Coronaviridae, dan subkeluarga Orthocoronavirinae, yang dibagi menjadi kelompok (marga) $\alpha, \beta, \gamma$, dan $\delta$ sesuai dengan karakteristik serotipik dan genomiknya. Virus Coronatermasuk dalam genus Coronavirus dari keluarga Coronaviridae. Ini dinamai sesuai dengan tonjolan berbentuk karangan bunga di selubung virus. Virus corona memiliki selubung yang membungkus genom RNA, dan 
virion (seluruh virus) bulat atau oval, seringkali polimorfik, dengan diameter 50 hingga $200 \mathrm{~nm}$. Virus corona baru berdiameter 60 hingga 140 nm. Paku protein terletak di permukaan virus dan membentuk struktur seperti batang. Sebagai salah satu protein antigenik utama virus, paku protein adalah struktur utama yang digunakan untuk penentuan tipe. Protein nukleokapsid merangkup genom virus dan dapat digunakan sebagai antigen diagnostik (Zhou, 2020).

Virus umumnya dapat bertahan selama beberapa jam di permukaan yang halus. Jika suhu dan kelembaban memungkinkan, mereka dapat bertahan selama beberapa hari. Virus corona baru sensitif terhadap sinar ultraviolet dan panas. Panas yang berkelanjutan pada $132,8^{\circ} \mathrm{F}$ selama 30 menit, eter, alkohol $75 \%$, desinfektan yang mengandung klorin, asam perasetat, kloroform, dan pelarut lipid lainnya dapat secara efektif menonaktifkan virus. Chlorhexidine (juga dikenal sebagai chlorhexidine gluconate) juga secara efektif menonaktifkan virus. Waktu kelangsungan hidup virus corona baru 2019-nCoV pada suhu lingkungan yang berbeda. Virus corona yang baru ditemukan ini adalah mutasi dari novel coronavirus ( $\beta$ genus), yang diberi nama 2019nCoV oleh WHO dan SARS-CoV-2 oleh ICTV. Pada 10 Januari 2020, sekuensing genom atas sampel pertama 2019-nCoV selesai dilakukan, dan urutan genom virus dari lima sampel berikutnya diumumkan setelah itu. Akibat mutasi antigenik yang membuat virus corona ini tidak dikenal oleh manusia, masyarakat umum tidak memiliki kekebalan terhadap strain baru virus ini. Selain itu, penularan virus ini terjadi melalui lebih dari satu cara. Faktor-faktor inilah yang mengakibatkan novel corona virus menjadi epidemi (Zhou, 2020).

COVID-19 dapat menyebar terutama dari orang ke orang melalui percikan-percikan dari hidung atau mulut yang keluar saat orang yang terinfeksi COVID-19 batuk, bersin atau berbicara. Percikan-percikan ini relatif berat, perjalanannya tidak jauh dan jatuh ke tanah dengan cepat. Orang dapat terinfeksi COVID-19 jika menghirup percikan orang yang terinfeksi virus ini. Oleh karena itu, penting bagi kita untuk menjaga jarak minimal 1 meter dari orang lain. Percikanpercikan ini dapat menempel di benda dan permukaan lainnya di sekitar orang seperti meja, gagang pintu, dan pegangan tangan. Orang dapat terinfeksi dengan menyentuh benda atau permukaan tersebut, kemudian menyentuh mata, hidung, atau mulut mereka. Inilah sebabnya penting untuk mencuci tangan secara teratur dengan sabun dan air bersih mengalir, atau membersihkannya dengan cairan antiseptik berbahan dasar alkohol. WHO terus mengkaji perkembangan penelitian tentang cara penyebaran COVID-19 dan akan menyampaikan temuan-temuan terbaru (WHO, 2020)

\section{Menurut WHO (2020) Gejala-gejala} COVID-19 yang paling umum adalah demam, batuk kering, dan rasa lelah. Gejala lainnya yang lebih jarang dan mungkin dialami beberapa pasien meliputi rasa nyeri dan sakit, hidung tersumbat, sakit kepala, konjungtivitis, sakit tenggorokan, diare, kehilangan indera rasa atau penciuman, ruam pada kulit, atau 
perubahan warna jari tangan atau kaki. Gejalagejala yang dialami biasanya bersifat ringan dan muncul secara bertahap. Beberapa orang menjadi terinfeksi tetapi hanya memiliki gejala ringan. Sebagian besar (sekitar $80 \%$ ) orang yang terinfeksi berhasil pulih tanpa perlu perawatan khusus. Sekitar 1 dari 5 orang yang terinfeksi COVID-19 menderita sakit parah dan kesulitan bernapas. Orang-orang lanjut usia (lansia) dan orang-orang dengan kondisi medis penyerta seperti tekanan darah tinggi, gangguan jantung dan paru-paru, diabetes, atau kanker memiliki kemungkinan lebih besar mengalami sakit lebih serius. Namun, siapa pun dapat terinfeksi COVID-19 dan mengalami sakit yang serius. Orang dari segala usia yang mengalami demam dan/atau batuk disertai dengan kesulitan bernapas/sesak napas, nyeri/tekanan dada, atau kehilangan kemampuan berbicara atau bergerak harus segera mencari pertolongan medis. Jika memungkinkan, disarankan untuk menghubungi penyedia layanan kesehatan atau fasilitas kesehatan terlebih dahulu, sehingga pasien dapat diarahkan ke fasilitas kesehatan yang tepat.

Menurut gugus tugas Covid-19 (2020), terdapat beberapa prinsip yang perlu diikuti untuk membantu mencegah persebaran virus pernapasan, yaitu menjaga kebersihan diri/ personal dan rumah dengan cara:

a. Mencuci tangan lebih sering dengan sabun dan air setidaknya 20 detik atau menggunakan hand sanitizer, serta mandi atau mencuci muka jika memungkinkan, sesampainya rumah atau di tempat bekerja, setelah membersihkan kotoran hidung, batuk atau bersin dan ketika makan atau mengantarkan makanan.

b. Hindari menyentuh mata, hidung, dan mulut dengan tangan yang belum dicucic. Jangan berjabat tangan dan hindari interaksi fisik dekat dengan orang yang memiliki gejala sakit.

c. Tutupi mulut saat batuk dan bersin dengan lengan atas dan ketiak atau dengan tisu lalu langsung buang tisu ke tempat sampah dan segera cuci tangan.

d. Segera mengganti baju/mandi sesampainya di rumah setelah bepergian.

e. Bersihkan dan berikan desinfektan secara berkala pada benda-benda yang sering disentuh dan pada permukaan rumah dan perabot (meja, kursi, dan lain- lain), gagang pintu, dan lain-lain.

Pencegahan level masyarakat yaitu pembatasan Interaksi Fisik (Physical contact/ physical distancing)

a. Tidak berdekatan atau berkumpul di keramaian atau tempat-tempat umum, jika terpaksa berada di tempat umum gunakanlah masker.

b. Tidak menyelenggarakan kegiatan/ pertemuan yang melibatkan banyak peserta (mass gathering).

c. Hindari melakukan perjalanan baik ke luar kota atau luar negeri.

d. Hindari bepergian ke tempat-tempat wisata.

e. Mengurangi berkunjung ke rumah kerabat/teman/saudara dan mengurangi menerima kunjungan/tamu. 
f. Mengurangi frekuensi belanja dan pergi berbelanja. Saat benar-benar butuh, usahakan bukan pada jam ramai.

g. Menerapkan Work From Home(WFH)

h. Jaga jarak dengan orang lain minimal 1 meter (saat mengantri, duduk di bus/kereta).

i. Untuk sementara waktu, anak sebaiknya bermain sendiri di rumah.

j. Untuk sementara waktu, dapat melaksanakan ibadah di rumah.

\section{METODE}

Kegiatan pengabdian kepada masyarakat dilaksanakan dengan rincian kegiatan diterangakan pada sub bab berikut ini.

\section{Persiapan}

Persiapan pelaksanaan kegiatan akan dilakukan bersama para anggota dengan mengurus perizinan kepada pihak panti (5 lokasi panti di Banda Aceh) terkait tempat acara serta peserta yang menjadi sasaran pengabdian yaitu penghuni panti yang berada di wilayah Banda Aceh. Pengabdi juga mempersiapkan alat dan bahan yang diperlukan untuk melaksanakan kegiatan seperti media pendidikan kesehatan tentang kebersihan tangan sesuai standar WHO yang diberikan berupa video untuk menghindari kerumunan serta mengikuti anjuran pemerintah untuk saling menjaga jarak serta pengabdi juga menyiapkan bahan alternatif kebersihan tangan yaitu hand sanitizer yang juga diberikan kepada penghuni panti.

\section{Pelaksanaan}

Pelaksanaan kegiatan akan dilakukan di lima lokasi panti di wilayah Banda Aceh yang dilakukan pada tanggal 03-05 Mei 2020. Sasaran pelaksanaan kegiatan pengabdian kepada masyarakat ini yaitu: Menjaga Kebersihan Tangan dalam mencegah penularan Covid-19 Pada Panti di wilayah Banda Aceh dengan sasaran para penghuni panti dengan berbagai jenjang usia yang sangat berisiko tertular Covid-19. Adapun tahapan kegiatan pengabdian ini adalah diawali dengan pendidikan kesehatan tentang kebersihan tangan serta demonstrasi yang diberikan melalui video yang telah dibuat dan diperagakan oleh pengabdi dan selanjutnya penghuni panti memperagakan gerakan yang telah pelaksana demonstrasikan, serta sesi terakhir adalah pemberian bantuan hand sanitizer sebanyak lima belas liter di lima lokasi panti di wilayah Banda Aceh.

\section{Evaluasi}

Evaluasi pelaksanaan kegiatan pengabdian ini dilakukan dengan melihat respon, serta pemahan penghuni panti dengan cara mampu mengulang kembali gerakan kebersihan tangan yang telah didemostrasikan oleh pengabdi sesuai standar WHO, diharapkan nantinya para penghuni panti dapat meningkatkan kesadaran tentang pentingnya kebersihan tangan agar terhindar dari penularan dan kesakitan akibat COVID-19, sehingga dapat meningkatkan kualitas dan harapan hidup para penghuni panti yang ada di wilayah Banda Aceh. 


\section{HASIL DAN PEMBAHASAN}

Pengabdian kepada masyarakat ini bertujuan untuk meningkatkan pengetahuan dan pemahaman masyarakat terkait pencegahan penularan pandemi covid-19 yang sedang terjadi saat ini. Pemilihan panti sebagai mitra pengabdian kepada masyarakat didasari dari belum pernah diberikannya pendidikan kesehatan khususnya kebersihan tangan sesuai standar WHO untuk mencegah penularan COVID-19 di panti-panti di wilayah Banda Aceh.

Pengabdi memilih lima panti yang dijadikan mitra, empat panti asuhan yaitu panti asuhan Nirmala, panti asuhan Muhamadiyah, panti asuhan Media Kasih, panti asuhan Penyantun Islam, serta satu panti jompo yaitu Rumoh Sejahtera Geunaseh Sayang.

Panti merupakan salah satu tempat yang rentan untuk tertular Covid-19 baik panti asuhan maupun panti jompo, dikarenakan panti merupakan tempat yang ramai, tempat yang sering melakukan interaksi sosial, dan bayak orang melakukan kunjungan ke panti seperti mengujungi saudaranya dipanti, memberikan sumbangan dan kegiatan-kegiatan lainya.

Pelaksana memberikan pendidikan kesehatan melalui video yang telah dibuat dan diberikan kepada pihak pengurus panti agar selanjutnya dapat dipelajari dan diterapkan kembali oleh penghuni panti. Pelaksana juga memberikan demontrasi menjaga kebersihan tangan di depan beberapa penghuni panti dan pengurus panti. Ini dimaksudkan agar penghuni panti dapat mendemonstrasikan kembali dengan tepat cara menjaga kebersihan sesuai standar WHO serta dapat membagi ilmu yang didapatkan lagsung pada penghuni panti lainnya tanpa harus membuat kerumunan masa.

Hasil pendidikan kesehatan dengan cara menjaga kebersihan tangan untuk mencegah penularan COVID-19 menujukan adanya peningkatan pemahaman para penghuni panti. Penghuni panti mampu mengulang kembali penjelasan terkait kebersihan tangan serta mempraktikan kembali cara mencuci tangan yang benar sesuai standar WHO.

Selain memberikan pendidikan kesehatan, pelaksana juga memberikan bantuan hand sanitizer sejumlah 15 liter pada lima panti diwilayah Banda Aceh. Bantuan ini merupakan bagian dari pengabdian cegah penularan Covid-19 dengan menjaga kebersihan tangan, yang mana hand sanitizer dapat digunakan untuk mengganti mencuci tangan jika tidak menemukan sumber air dan sabun. Penghuni panti juga dapat mempraktikan kembali cara penggunaan hand sanitizer yang benar dan menyebutkan kembali waktu-waktu yang tepat dalam penggunaan hand sanitizer.

Hasil pemberian pendidikan kesehatan ini diharapkan dapat diterapkan sesering mungkin setelah aktifitas yang memerlukan kebersihan tangan sehingga dapat menjadi salah satu pencegah penularan Covid-19. Pihak panti juga mengharapkan kegiatan-kegiatan lainnya yang serupa dapat dilakukan kembali dipanti guna memaksimalkan pemahaman penghuni panti akan pencegahan COVID-19. 


\section{KESIMPULAN}

Pemberian pendidikan kesehatan menjaga kebersihan tangan yang diberikan dalam bentuk digitalisasi (video edukasi) dapat meningkatkan pemahaman penghuni panti tentang kebersihan tangan. Salah satu cara pencegahan penularan COVID-19 yaitu mencuci tangan yang benar menurut standar WHO dan penggunaan hand sanitizer yang tepat diharapkan mampu diterapkan dalam seluruh aktifitas penghuni panti sehingga dapat meningkatkan standar kesehatan serta mencegah penularan COVID-19 di lingkungan panti diwilayah Banda Aceh.

\section{UCAPAN TERIMAKASIH}

Ucapan terima kasih kami pada pengelola dan pengurus panti yang telah memberikan izin untuk melakukan pengabdian, serta seluruh penghuni panti yang dengan semangat dan aktif menerima pendidikan kesehatan yang diberikan pelaksana.

\section{DAFTAR PUSTAKA}

Direktorat Jendral P2P. (2020). Pedoman Pencegahan dan Pengendalian Corona Virus Disease (COVID-19). Germas : Kementrian kesehatan Republik Indonesia.

Kementrian kesehatan Republik Indonesia. 2020. Halodoc: Menghadapi Covid-19 (buku panduan anti panik dari \#temanhidupsehat).

Zhou, Wang MD. (2020). The Corona Virus Prevention Hand Book: 101 Sciencebased Tips The Could Save Your Live. China.

WHO. (2020). Diakses pada : https://www. who.int/indonesia, 